\title{
Trantsizioa eskola txikietatik bigarren hezkuntzara. Aldagai lagungarrien bila
}

\author{
Nahia Intxausti Intxausti \\ Didaktika eta Eskola Antolakuntza \\ Donostiako Irakasleen Unibertsitate Eskola \\ Euskal Herriko Unibertsitatea (UPV/EHU) \\ Ainhoa Odriozola Aldalur \\ Donostiako Irakasleen Unibertsitate Eskola \\ Euskal Herriko Unibertsitatea (UPV/EHU) \\ Justo Bereziartua Zendoia \\ Didaktika eta Eskola Antolakuntza \\ Donostiako Irakasleen Unibertsitate Eskola \\ Euskal Herriko Unibertsitatea (UPV/EHU) \\ Harkaitz Zubiri Esnaola \\ Hizkuntza eta Literaturaren Didaktika \\ Donostiako Irakasleen Unibertsitate Eskola \\ Euskal Herriko Unibertsitatea (UPV/EHU)
}

DOI: $10.1387 /$ tantak.15559

GAKO-HITZAK: hezkuntza trantsizioak, eskola txikiak, familia-eskolakomunitatea harremana.

\section{SARRERA}

Lan honek Lehen Hezkuntzako Eskola txikian ikasi duten ikasleen Bigarren Hezkuntzarako trantsizio prozesua aztertzen du. Jakinekoa da Eskola Txikiek ezaugarri berezi batzuk partekatzen dituztela eta horrek ikasleen ikaskuntzan ondorioak dituela, besteak beste, trantsizio prozesuan. Lehen Hezkuntzatik (LH) Derrigorrezko Bigarren Hezkuntzarako (DBH) trantsizio prozesuaren garrantzia azpimarratu nahi da, batetik, ikasleek aldaketa ebolutibo garrantzitsuak bizi dituztelako, nerabezaroari lotuta, eta bestetik, trantsizio prozesuan sortzen diren zailtasunak gainditzeko moduak ikasleen ibilbide akademikoan arrastoa utzi dezaketelako. Lanaren helburua da ikasle, familia eta irakasleek trantsizioa nola bizi duten azter- 
tzea, identifikatu ahal izateko zeintzuk izan daitezkeen trantsizio prozesua erraztu eta zailtzen duten aldagai-giltzarriak. Horretarako, trantsizioaren eta Eskola Txikien inguruko ekarpen teorikoak jasotzen dira lehenik, ikerketaren ezaugarriak adierazi eta emaitzak azaltzen, ondoren, eta azkenik, ondorioak eztabaidatzen dira.

\section{MARKO TEORIKOA}

\section{Trantsizioaren inguruko ikuspegiak}

Definizio ugari aurki daitezke hezkuntza-trantsizioaren inguruan. Lan honetan Hanewald-ek $(2013,62)$ Australiako Hezkuntza eta Haurtzaroaren Garapen Departamenduak (DEECD, 2011) jasotzen duena hartu dugu aintzat, honela dio: «Aldaketa aldia da trantsizioa, desafiatzailea eta zirraragarria izan daitekeena, non familiak eta ikasleak rol, identitate, espektatiba, elkarrekintza eta erlazio berrietara egokitzen diren». Trantsizioa Lehen Hezkuntzako azken urtetik Bigarren Hezkuntzako lehen urtearen amaiera bitarteko tarteari dagokio.

Hezkuntza etapa batetik besterako trantsizioa eremu desberdinetatik aztertu izan da. Hanewaldek (2013) egindako literatura errebisioak erakusten du mota askotakoak direla trantsizio prozesuak, baita hartan eragina duten aldagaiak ere,. Lan honetarako bi ardatz aztertu dira. Alde batetik, psikologia eremuko lanak daude, ikasleek dituzten ezaugarri intrapertsonalek eskola berrirako egokitzapena nola baldintzatzen duten aztertu dutenak. Bestalde, hezkuntza eremutik, irakasle, ikasle eta familien hautemate eta rolek ikasleen egokitzapena nola baldintzatzen duten aztertu duten lanak daude.

Nazioarteko ikerketa gehienek trantsizioa aztertzeko ikerketa kuantitatiboa erabili dutebatez ere, eta kasu gutxitan osatu dira ikerketa hauek teknika kualitatiboekin. Herrialde batetik besterako hezkuntza sistema eta testuinguru sozialen arteko aldeak egonik ere, badira trantsizioaren ikerketan aztertu diren aldagai komunak. Eremu psikologikoan, aldagai intrapertsonalei lotuta hiru hurbilpen azpimarratuko ditugu.

Batetik, alderdi sozioemozionalei lotutakoak,, motibazioan eta errendimenduan ikasleen taldeetan parte izatearen sentimenduak eta funtzionamendu sozioemozionalek duten garrantzia aztertu dute (Cueto, 2010). Ikastetxearekin lotura positiboa izatea ikaskideekin arazo emozional gutxiago eta gaitasun prosozial hobeak izatearekin erlazionatu da (Waters, Cross eta Shaw, 2010). Lan horiek eta beste batzuek (Chedzoy eta Burden, 2005; Horward eta Johnson, 2004) erakusten dute trantsizio aldian alderdi sozialei ikasleek ematen dieten garrantzia, hots, lagunak egiteari eta ikaskidetaldean egoki txertatzeari ematen zaion lehentasuna. Institutuetan biltzen den jende multzo handian aukera gehiago izaten da Lehen Hezkuntzako lagun-talde iraunkorrak desegin eta berriak sortzeko. Kontuan izan behar da 
trantsizioa une bereziki kritikoa dela bullying egoerak pairatzeko, hierarkia soziala berregituratu egiten den eta ikasleak beren posizio soziala lortzeko lehiatzen diren unea delako. Gorabehera horiek gertatzen diren nerabezaro garaian berebiziko garrantzia dute nortasun-irudiak, identitateak eta lagun arteko estatusak (Pratt \& George, 2005).

Bestetik, ikasleen ongizate psikologikoarekin lotutako lanak daude; egokitzapen arazoak ondorengo aldagaiekin erlazionatu dira: autoestima eta gaitasun txikiagoa, depresio maila eta jarrera anti-sozial handiagoak (West, Sweeting eta Young, 2010), antsietate, depresio biktimizazio egoera eta bakardade txikiagoak (Waters et al. 2012). Egokitzapenak suposatzen duen estres egoeraren bizipen pertsonalen arabera, etapa batetik besterako jauzia hautemateko moduan alde handia dago (Mackenzie, McMaugh eta O'Sullivan, 2012).

Azkenik, Bigarren Hezkuntzako eskaera akademikoei erantzuteko ikasleek adierazten dituzten gaitasun akademikoak aztertu dira, adieraziz trantsizioa errazten dutela: ikasleak duen ezagutza-egokitasuna, pentsatzeko gaitasuna, modu independentean lan egiteko gaitasunak (Anderson et al., 2000) eta arazoen aurrean estrategia anitz erabiltzeak (Mackenzie, McMaugh eta O'Sullivan, 2012). Espektatibekin lotuta, Waters, Lester eta Cross-ek (2014) trantsizio esperientzia positiboa ikasleen espektatiba positiboekin lotu zuten.

Hezkuntzan ertz askotatik begiratu izan zaio trantsizioari. Batetik, ikerketa batzuek ikaskide, familia eta irakasleen babesa dituzte aztergai. Ondorioztatu dute ikasleek adiskidetasun lotura estuak izateak trantsizioa hobeto egiten laguntzen duela (Anderson et al., 2000; Weller, 2007; Kingery, Erdley eta Marshall, 2011). Halaber, irakasleek ikasleak babestu eta haien arteko erlazio positiboa bultzatzeko duten gaitasunak eragin positiboa du ikasleen trantsizioan (Ganeson eta Ehcrich, 2009), lan egiteko motibazioan eta ongizate sozial eta emozionalean (Bru et al., 2010). Familiek babesa eskaini, jarduerak monitorizatu eta esku-hartze positiboak eskaintzeak trantsizioa errazten laguntzen du (Smith, Feldwisch eta Abell, 2006; Smith et al., 2008). Adibidez, Crosnoe-k aztertu zuen (2009) familiak eta Lehen eta Bigarren Hezkuntzako eskolak harremanetan zeudenean harreman sare horrek hizkuntza mailen arteko aldeak gutxitzen zituela. Mackenzie, McMaugh eta O'Sullivanek (2012) etxeko sostengua izateak eta senide zaharragoren bat aurretik Institutura igaro izanak edota sare egituratu eta sendo baten elkarlana agertzeak trantsizioan laguntzen zutela ondorioztatu zuten.

Bestetik, trantsiziorako bi hezkuntza etapen arteko jarraipen pedagogikoaren garrantzia azpimarratu da. Alde nabarmenak identifikatu dira kolaboraziorako kulturari, irakasleen egitekoei eta curriculumaren edukiei (Gairin, 2005; Gimeno, 1996; Pietarinen, Pyhältö eta Soini, 2010) eta irakaskuntza estiloei lotuta (Monarca, Rappoport eta Fernándezek, 2012; Monarca, 2013). Galton, Morrison eta Pell-ek (2000) jasotzen dituzte 
ORACLE ikerketaren datuak, LHko azken bi urteak eta DBHko lehen urtean ikasle eta irakasleak behatu zituen ikerketak. Ondorioztatu zuten etapa batetik bestera eten garrantzitsuak zeudela eduki eta metodologiari dagokionean.

Azkenik, trantsizioa zaildu edo errazten duten hezkuntza aldagai garrantzitsuak zein diren ere aztertu da trantsizioan protagonista diren pertsonen- ikasle, familia, irakasleen- hautemateetatik abiaturik. Ikerketa horiek zera adierazten dute, ikasleentzako, oro har, trantsizioa ez dela arazoa eta gainditzen den prozesua dela (Anderson et al., 2000; Gimeno, 1996; Mackenzie, McMaugh eta O'Sullivan, 2012; Monarca, Rappoport eta Fernández, 2012), lehen hilabeteetako ondoezaren ostean (Monarca, 2013; Waters, Lester eta Cross, 2014). Baina Gairinek dioen bezala (2005) trantsizioa ikasleen heldutasun pertsonal eta soziala laguntzen duen prozesua bada ere honek ikasle batzuentzako erregresio bat suposa dezake. Eskola porrotaren inguruan egindako ikerketek erakutsi dute egoera ahulenean dauden ikasleentzat trantsizioak hezkuntza ibilbidean negatiboki eragin dezakeela (San Fabián, 1999; Monarca, Rappoport eta Fernández, 2012; Pietarinen, Pyhältö eta Soini, 2010; Monarca, Rappoport eta Sandoval, 2013). Eskolek trantsizioa egoki prestatzea, beraz, ekitate eta justizian oinarritutako hezkuntza baten aldeko urrats bilakatzen da (Antúnez, 2005). Horra hor estrategia inklusiboak aktibatzeak duen garrantzia, hots, ikasle guztien garapen orekatua bilatu eta ezberdinkeriari aurre egiteak.

Trantsizioa prozesua aberasgarria ere izan liteke, ikasleentzako ikaskuntza aukera, eskola komunitatean duten birnegoziatzeko. Trantsizioa errazteko berariazko trantsizio-programa edo -ekintzak baliagarriak direla ikusi da (Hanewald, 2013; Galton, Morrison eta Pell, 2000; Pietarinen, Pyhältö eta Soini, 2010). Ikastetxeen arteko komunikazio eta kolaborazio egokia da gakoa; bi norabideetan, ikasleek eta familiek eskola ezagutzen eta alderantziz (Antúnez, 2005). Ikasleentzako eta beren familientzako harrera-plana zehaztu liteke trantsizioaren etapa guztian eskolaren ezaugarrien ezagutza ziurtatzeko (Domènech, 2000). Halaber, ikasleen behar, interes eta zailtasunak identifikatu behar ditu eskolak, trantsizioaren ondorioz sor daitezkeen aldaketen prebentzio eta detekzioa egiteko, arlo psikologikoan (larritasuna, beldurra, erresistentzia), akademikoan (jarrera, interesa eta motibazioa ikaskuntzarekiko, ikasteko ohiturak) eta sozialean (ikaskide taldean eta eskolan integratzea) (Martínez eta Lledó 2005). Antúnezen ustez (2005) lagungarria da eskolek antolakuntzan zuzenean eragiten duten erabakiak aurreikustea: tutoretza-plan egokia, taldekatze-sistema egokiak, eduki curricularren nahiz elkarbizitza erregulatzeko mekanismoen errebisioa, edota jatorrizko ikastetxearekin sintonian dauden metodologia estrategikoak. Kolaborazioaren azken helburua bere instituzionalizazioa da, trantsizioaren inguruko gaiak ikastetxe mailako ardura gisa ulertuta (Antúnez, 2005). 
Zehazki, Eskola Txikitik Institutura egiten den trantsizioa aztergai dugunez, Eskola Txikiaren ezaugarriak jasoko dira ondoren.

\section{Eskola Txikiak}

Landa eremuko eskolak antolakuntza propioa duten ikastetxeak dira, auzo edo herriko eskola bakarrak (Boix, 2004). Gipuzkoan, Eskola Txikien balioaz jabeturiko irakasle talde batek bultzatuta, elkarlanari ekin zioten 1987. urtean. 1993. urtean zortzi-hamar herritako guraso elkarteek Gipuzkoako Eskola Txikietako Guraso Elkarteen Koordinadora sortzea erabaki zuten, eta bertan helburu nagusiak onartu zituzten estatutu bidez: eskola publiko euskalduna herrietan mantentzea, herriaren nortasunean eta kulturan oinarritutako eskolen beharrak azaldu eta eskakizunak bideratzeko heziketa bultzatzea, eta herri txikien arteko harremanak sustatzea, eskolaz kanpoko jarduerak bitarteko hartuta. Azkenik, 2003.ean Eusko Jaurlaritzako Eskola Txikien Batzordea sortu zen; gaur egun, Gipuzkoa eta Bizkaiko guraso eta irakasleek, koordinatzaileek eta Hezkuntza Ordezkaritzak osatzen dutena.

Boixen esanetan $(2004$; 2011) Espainian landa eremuen berpizkundea ekarri zuen gizarte post-moderno berberak gaitasun pedagogikoen indartzea ere eragin zuen, eta eskola inklusiboaren ideiak saretzen hasi ziren. Landa eremuko eskolek bertako kultura, ingurua eta aniztasunean oinarritutako egitura pedagogiko didaktikoak dituztela dio. Autore batzuek (Bustos, 2007; Tonucci, 1996) ikaskuntza eta irakaskuntzako proiektu berritzaileak aurrera eramateko aparteko testuinguruak direla diote. Berlangaren ustez (2003) iraultza pedagogiko garrantzitsuak dituzte ezaugarri: ikasle eta irakasleen arteko harreman estua, ikaskuntza bizitzari lotua, familia ereduetatik gertuagoko antolaketa, familiarekin lotura estuagoa, etab. Eskola Txikiak printzipio naturalen arabera gidatzen dira, eta horiek - egilearen aburuz - eskola hiritarrek duten antolaketa moduarekin galdu egin dira neurri handi batean.

Gure testuinguruko Eskola Txikien ezaugarri adierazgarriena, Olanoren ustez (2012), gelako adin aniztasuna da. Horrez gain, Eskola Txikiak herri txikietan kokaturik egoten direla dio, nekazal kutsu nabarmena duten herrietan eta euskararen bizi-indarra sendoa denetan. Ez dituzte sei gela baino gehiago izan ohi. Eskola Txikietan hezkuntzako metodologia jakin bat aplikatzen dela dio, eta horretarako, herri horietako irakasleek formazio berezia jasotzen dute metodologia hori ezagutu dezaten eta proiektu bidez lan egin dezaten. Sepúlveda eta Gallardoren (2011) ustez Eskola Txikien hezkuntza-egoeraz hausnartzea konplexua da, baina horrek ez du eragotzi behar hezkuntza, ekonomia, politika eta administrazio sozialek testuinguru horiek kontuan ez hartzea.

Ikerketei dagokienean, landa eremuetako eskolei buruzko ikerlanen hutsunea dago estatu Espainiarrean eta nazioartean (Bustos, 2008). Gurean 
egin diren ikerketak urriak izan dira. Aipatzekoak dira Gipuzkoako udalek, Aldundiak eta bizilagunek 1900-1950 urteetan landa eremuan martxan jarritako hezkuntza politiken inguruko lana (Garmendia, 2003). Halaber, Manzisidorrek (2013) Eskola Txikien egungo egoera eta etorkizuneko erronkak aztertu zituen haietako irakasle, ikasle ohi eta familiekin. Etxebestek (1994) Gipuzkoako Eskola Txiki batean ikaskuntza-irakaskuntza prozesuaren kasu-azterketa egin zuen, eta ondorioztatu zuenez, ikasleek eskola esperientzia beren testuinguru hurbila osatzen duten eragileen bidez jasotzen zuten eta irakasleak esperientzia horietatik abiatuta antolatzen zuen bere irakaskuntza-jarduera, berdintasunezko harremanak bultzatuz. Bengoetxea, Arribillaga eta Madariagak (2012) Bizkaiko Eskola Txiki bateko hezkuntza-praktikak behatu zituzten, eta ondorioztatu zuten praktikak espero baino gehiago urruntzen zirela konstruktibismoaren oinarrietatik eta ikasleen parte-hartzea desberdina zela ikasleek zuten hezkuntza maila eta jatorri kulturalaren arabera. Azkenik, Gipuzkoako Eskola Txiki batean, bertako irakasle talde batek eta unibertsitateko irakasleek lankidetzan egindako berrikuntza proiektua dago (Cruz et al., 2010).

Esan daiteke, ordea, Eskola Txikietatik Bigarren Hezkuntzarako trantsizioa aztertu duen lanik ez dagoela, eta, beraz, lan hau hutsune hori betetzera datorrela.

\section{IKERKETAREN HELBURUAK}

Ikerketa honen helburu nagusia da Eskola Txikiko Lehen Hezkuntzako ikasleek Bigarren Hezkuntzara egiten duten trantsizioa aztertzea. Helburu nagusi hori lortzeko ondorengo helburu espezifikoak jarraitu ditugu:

- Trantsizio prozesuan ikasleen trantsizio esperientziari buruzko bizipenak ezagutzea.

- Eskola Txikiko eta Bigarren Hezkuntzako ikasle horien irakasleek trantsizio prozesuari buruz dituzten hautemateak azaleratzea.

- Ikasle horien gurasoek trantsizioaren inguruan dituzten hautemateak ezagutzea.

\section{METODOLOGIA}

Ikerketa honetarako metodologia kualitatiboa hobetsi da, eta kasu-azterketa izan da erabilitako teknika. Lehen Hezkuntzako bi Eskola Txiki aztertu dira. Stake-n (2000) irizpideei jarraituz, kasua ulertzea lehenetsi da, helburua ulertu nahi den fenomenoaren ezaugarri bereizgarriak aztertzea delako, bere konplexutasuna ulertzeko, eta ez orokortasunak nabarmentzea. Ikerketa-galderak dira kasu azterketaren egitura kontzeptuala, azter- 
gai den kasuaren ulermena sakontzeko ardatzak. Janesick-ek (2000) dioenez, ikuspegi kualitatibotik aritzean, ikertzaileak analisi induktiboa egiten du. Hau da, landa-lanean jasotako informaziotik eratortzen dira kategoriak, gaiak eta ereduak, nahiz eta ikertzaileak aurretik diseinatu behar dituen informazioa kodifikatzeko eta sailkatzeko irizpideak, prozesuan zehar alda daitezkeenak. Kontziente gara, ordea, Angrosino eta Mays de Pérezen (2000) ekarpena kontuan hartuz, egia objektiboak ezartzea ezinezkoa dela. Adituen lekukotasunak halabeharrez oinarrituko dira genero, klase, etnia eta bestelako baldintzen eraginpean. Ondorioz, subjektu ikertzailea eta objektu ikertua baino, esan genezake ikertzaileen eta deskribatu nahi denaren arteko elkarrizketa dagoela. Beraz, ikerketaren funtsa lankidetza da, diziplinen artean ez ezik, baita ikertzaile profesionalen eta subjektuen artean ere. Horrexegatik komenigarria izan daiteke behaketa per se metodotzat hartu baino lankidetza hartu-emanetarako testuingurutzat ulertzea, beti ere irizpide hauek kontuan hartuz: landa-lanean hartzen den nortasuna kontzienteki eraikitzea, botere harremanen galbaheaz jabetzeko ahalegina egitea, landa-laneko nortasunaren negoziazioa prozesu etengabe eta moldagarria izatea, norberak besteengan duen eraginaz konturatzeko ahalegina egitea, eta esanahia testuinguruan kokatzea, ikertzailearekiko erreakzioa dena eta ez dena bereiziz.

\subsection{Lagina eta datu bilketarako tresnak}

Eskola Txikien Gipuzkoako koordinatzaileek aukeratu zituzten Gipuzkoako bi Eskola Txiki, kasu azterketarako. Ikerketako parte hartzaileak anitzak izan dira, 2 Eskola Txikietako eta horien erreferentziazko Derrigorrezko Bigarren Hezkuntzako ikastetxeetako ikasle, irakasle eta familiak:

- Ikasleak: Solasaldi gidatuetan LHko 6. mailako 6 ikaslek eta DBH 1. mailako 11 ikaslek parte hartu dute. Gainera, Lehen Hezkuntzako 5. eta 6. mailetako bi gela behatu dira. Gradu aniztun ikasgelak izanik, bosgarren eta seigarren mailetakoek elkarrekin ikasten dute.

- Irakasleak: bi ikastetxeetako Lehen Hezkuntzako 9 irakasle eta DBHko 6 irakasle.

- Familiak: Lehen Hezkuntzako 6. mailako ikasleen 10 gurasok, eta DBH 1. mailako ikasleen 6 gurasok parte hartu dute.

Ikerketa kualitatiboaren testuinguruan ondorengo teknika eta tresnak erabili ditugu datuen bilketarako: behaketa, solasaldi gidatua, dokumentu analisia eta mintegia. Ikerketa kualitatiboaren funtsa fenomeno sozialetan gertatzen diren «unibertsal zehatzen esanahi osotuak» jasotzea da (Ruiz Olabuénaga, 2009, 24). Gauzen esanahiak jaso eta horiek ikuspegi holistiko batetik berreraikitzeko helburua izanik, informazioa jasotzeko modua malgua eta desestrukturatua behar da izan. Horrenbestez, horri erantzun 
ahal izateko lan honetan behaketaren eta solasaldi gidatuaren teknikak hobetsi dira. Dokumentu analisia ere estrategia kualitatibo gisa hobetsi da, ikerlariak testuaren analisiaz gain, haren interpretazioa eta berreraikitzea ere egiten dituela ulertuta. Azkenik, mintegiak burutu dira. Izan ere, ikerketaren funtsa ikertzaile profesionalen eta subjektuen arteko lankidetza izanik, garrantzitsua ikusi da ikerketaren prozesua amaitzear zenean subjektuekin elkar jartze saioa egitea.

1. Ikasgelako behaketa: behaketa egitea hautatu da ikasgela barruko antolaketa eta irakaskuntza-ikaskuntza egoerek duten esanahia berreraikitzeko, arestian esan bezala behaketa lankidetza hartu-emanetarako testuinguru bezala ulertuaz. Aztertutako bi Eskola Txikietako ikasgeletan egin dira, Lehen Hezkuntzako 6. mailako ikasleak zeuden ikasgelan, beste adinekoekin batera. Guztira, 68 behaketa ordu izan ziren. Eskola bakoitzean bi ikertzailek, orotara, 14 egunetan egin zuten behaketa, eta egun horietan 39 ordu eman zituzten behaketan (6 egun eta 21 ordu ikertzaile batek, eta 8 egun eta 18 ordu besteak). Beste eskolan, berriz, ikertzaileek 15 egunez egin zuten behaketa, eta egun horietan 29 ordu eman zituzten behaketan (7 egun eta 15 ordu ikertzaile batek, eta 8 egun eta 14 ordu besteak).

2. Solasaldi gidatuak: hamasei solasaldi gidatu edo Focus Group (Barbour, 2007) egin ziren, aztergai bakoitzean 8.

\begin{tabular}{lcccc}
\hline & \multicolumn{2}{c}{ Lehen Hezkuntza, 6.maila } & \multicolumn{2}{c}{ Bigarren Hezkuntza DBH, 1. Maila } \\
\cline { 2 - 5 } & $\begin{array}{c}\text { Urria-abendua, } \\
2013\end{array}$ & Martxoa-maiatza, & Urria-abendua, & $\begin{array}{c}\text { Martxoa-maiatza, } \\
2014\end{array}$ \\
\hline Ikasleekin & 2013 & 2 \\
Irakasleekin & 2 & 2 & 2 \\
Gurasoekin & 2 & & 2 \\
\hline
\end{tabular}

3. Dokumentu-analisia: Bigarren Hezkuntzan dauden Eskola Txikiko ikasle ohien gelako lan-koadernoak aztertu ziren. Kategoria orokorrenak ardatz hartuta, ikasgelako jarduera didaktikoak aztertzeko baliatu ziren.

4. Mintegiak: ikerketa datuak jaso eta analisia amaitu ondoren parte hartzaile guztiei behin-behineko txostena eman zitzaien iruzkinak egin zitzaten. Ondoren, hiru mintegi saiotan iruzkin horiek jaso eta txostenari ekarpen berriak egin zitzaizkion. Bi mintegi eskola bakoitzeko familia multzoekin, eta hirugarren mintegia parte hartu zuten Lehen Hezkuntzako irakasleen taldearekin (bi eskolak batera) burutu ziren. Bigarren Hezkuntzako ikastetxeekin ez zen mintegirik antolatu. 


\subsection{Datuen bilketa eta azterketa}

Datuen bilketa 2013. urteko urrian hasi eta 2014ko azaroan bukatu zen. Informazioaren analisia metodologia kualitatibo induktiboaren bidez egin zen. Behaketa egin ahala, bildutako landa-oharretan eta solasaldi gidatuetan jasotako testuen lehen irakurketan, ikergaiari lotutako osagai batzuk identifikatu ziren abiatzeko: irakasleen rolak, ikasleen eta irakasleen arteko harremana, espazioen eta denboraren antolaketa, irakaskuntza eta ikaskuntzako metodologia, ikasleen bizipenak trantsizioaren aurrean, ebaluazioa, ikastetxeen arteko koordinazioa, eskola ingurunearen testuinguru soziokulturala eta tutoretza plana. Hortik aurrera, analisi unitateak sailkatu eta multzoak sortu ziren irizpide tematikoak erabiliz.

Informazioa biltzeko baliabide nahiz iturri bat baino gehiago erabilita, triangulazioak egin ahal izan dira. Tekniken triangulazioa batetik eta, gero, informazioa eskuratu ahala, kategoria-sistemaren eraikuntzan ikertzaileen triangulazioa (Rodríguez, Gil eta García, 1996; Padilla, 2002), azterlanean esku hartu dutenen artean eztabaidan jardun eta ikuskerak bateratzen ahaleginduz.

Informazio bilketa oso aurreratuta zegoela, ikuspegi orokor eta integratzaileagora itzulita, gaiaren analisiari ekin zitzaion berriro, lehengo osagaiak berreskuratu eta analisi eremu zabalagoetan ikusteko. Hiru eremu orokor bereizi ziren: 1) trantsizio prozesua erraztu dezaketen alderdiak, 2) prozesua zailtzen duten alderdi iraunkorragoak eta 3) trantsizioa zailtzen duten aldi baterako alderdiak. Horrez gain, Eskola Txikietako ikasgeletan bildutako informazioan agertzen diren hainbat une eta gertaera didaktikok ikastearen inguruko eztabaida zabaldu zuten.

Gaien analisia egiteko gida modura, ikasleen trantsizioa aztertzen eta deskribatzen laguntzen duen diagrama eskematikoa eraiki zen, eta gero, sintesia eta emaitzen aurkezpena egiteko ere erabili. Artikulu honetan soilik trantsizioa errazten duten aldagaien inguruko datuak aurkezten dira.

\section{EMAITZAK}

Trantsizioa erraztu dezaketen alderdien inguruan lortutako emaitzak azalduko dira ondoren, hainbat datu iturri aintzat hartuaz. Ez dirudi alderdi horiek erabat bermatzen dutenik trantsizioa errazagoa izatea, baina jaso ditugun datuek iradokitzen dute eragin handia dutela trantsizioan.

\subsection{Koordinazio pedagogikoa}

Eskola Txikiaren eta Bigarren Hezkuntzako Institutuaren arteko koordinazioa irakasleen diskurtsoan gailendu den giltzarrietako bat da. Aztertu 
diren bi eskolen artean desberdintasunak identifikatu badira ere, koordinazio pedagogikoaren edukiak ondorengoak dira: batetik, ikasleei buruzko informazioa partekatzen dute, eta horretarako bilerak egiten dituzte tutore eta zuzendaritzako kideen artean ikasturtea hasi aurretik, eta ikasleak DBH 1. mailan daudenean.

«Koordinazioa egiten da, hemengo ikasketa buruak joaten gara ikastetxe ezberdinetara, ikasle bakoitzaren datuak jasotzen dira akademikoki, maila pertsonalean, zer arazo izan ditzaketen, zer alde on, hori egiten da bai [herri honetakoekin] bai gainerakoekin, eta gero... eta gero guk pasatzen diegu tutoreei» (Bigarren Hezkuntzako irakaslea).

Beste elementu bat curriculum-diseinuaren zenbait ikuspegi partekatu eta adostea da, adibidez, ebaluazioen gutxienekoak. Koordinazio horren aldagai baldintzatzaileetako bat DBHko ikastetxearen tamaina da. DBHko eskola handien kasuan, LHko ikastetxe ugari dituzte, eta LHko eskola horiek desberdinak izanik, koordinazioa zaildu egin daiteke (zein gai ukitu, maiztasuna, aldaketak egiteko irekiera...). Ordea, LHko ikastetxe asko bileretan egotea ere lagungarri gerta liteke, elkarren artean ideiak partekatzeko eta beraien lana osatzeko. Bilera horietan LHko irakasle-tutoreak eta DBHko koordinatzailea eta orientatzailea biltzen dira, eta akta bidez LHko irakasle eta DBHko mintegietara pasatzen dituzte erabakiak.

«Ikastetxe ezberdinetako programazioak aztertzen dira. Gero bakoitzak bere teknikak ditu, koordinazio bilerak. Batzuek testu liburuak erabiltzen dituzte, batzuek metodologia tradizionalagoak erabiltzen dituzte... momentu askotan gurekiko baino, beraiekiko... zuk zer egiten duzu eta zuk zer eta abar.... ondo etortzen zaie, zeren askotan bakarrik sentitzen zara, zu bakarra zara, (...) ematen du aukera hitz egiteko, konparatzeko, zer egiten ari zaren, noraino...» (Bigarren Hezkuntzako irakaslea).

Azkenik, beste koordinazio elementu bat Institutua ezagutzeko ekimenak dira. Hori lagungarri da, ikastetxea bertatik bertara ezagutzeaz gain, Institutuan izango duten hezkuntza ereduaren ezaugarrien jakitun izateko.

«Urtarrila bukaeran, otsaila hasieran, [Institutura] jaisten dira, beste eskolara joaten dira, baina hauek gutxi direnez, [Institutura] jaisten dira (...), 1. mailan zer arlo, nola funtzionatzen duen eskolak, eta aukera ematen die ikasleei ere joateko eta eskola ezagutzeko» (Lehen Hezkuntzako irakaslea).

Ez dirudi elkar ezagutzeko ekimen horiek beti arrakastatsuak direnik, kontuan izanik egiten diren ekintza batzuek ez dutela lortzen, parte hartzaile batzuen ustez, ikasle taldeen arteko interakzioa. Bisitak burutu eta kirol ekintzak egiteko ikasle taldeak eskolaka antolatzen dituzte eta Eskola Txikietako partaideak, gutxi izanik, bakartu samar gelditzen dira. 
«Helburua izaten da.. eskola erakutsi egiten diete, ezta? Hori da helburua (...) Eta haurrak elkarren artean ezagutu. Baina, justu horrela, bakoitzak bere ghettoa izatea... bultzatzen da.» (Lehen Hezkuntzako irakaslea).

\subsection{Sozialki mundua zabaltzea}

Aho batez onartzen dute - parte hartzaile guztiek - sozialki zabaltzen zaien mundua dela motibazio indartsuena Institutura abiatzeko. Norberaren hurbileko eremutik urrunago dauden espazio berriak ezagutzeko, lagun berriak eta adinkideen taldeak handitzeko aukera zabaltzen zaie. Ikuspegi hori bereziki da interesgarria Eskola Txikietatik doazen ikasleentzat. Izan ere, ikasle adinkide gutxi egonik, ez dute laguntasun aukera askorik izaten. Aitzitik, askotan kopuru txikiek horretara behartzen dituzte. Guraso eta irakasleek, bereziki, beharrezko pausutzat dute aldaketa hori, ikasleen garapen pertsonala eta sozialerako, eta egoera berrietara egokitzen ikasteko onuragarria zaielako.

«Gogoz. Jende gehiago dago, eta ja gogotsu nago jende gehiago ezagutzeko.» (Lehen Hezkuntzako ikaslea)

«Nik uste dut batzuk desiratzen daudela hona etortzeko. Mundua ireki egiten zaie. $\mathrm{Zu}$, bestela, kondenatuta zaude lau adin bereko-eta ondo moldatzera, nahiz eta haiekin zerikusi handirik ez izan. Eta hona etortzen dira eta askatzen dira.» (Bigarren Hezkuntzako irakaslea).

«Kaltegarri bezala ezer ez diat ikusten, zeren herrian lotura eginda zaukatek, harremana segitzen dute edukitzen, gazteagoekin, txikiagoekin, bere adinekoekin, denekin. Eta aspektu positibo bezala, kanpora zabaltzen zaiela, lagun pila bat egiten dituztela.» (Bigarren Hezkuntzako ikaslearen gurasoa).

Gurasoek onartzen dute garai hori harremanen zabalgune ikuspegitik ikasleentzako kitzikagarria den bezala, kezka iturri ere badela, hain zuzen Institutuan adinez ikasle nagusiago eta nerabezaroan bete-betean sartutako ikasleekin elkartuko direlako.

«Ilusioa pizten duen garaia da. Jadanik ez dira hain umeak. Bestetik, beldur pixka bat, kakotx artean, (...) zure alaba hamazazpi urteko neska-mutilekin elkartuko dela ikustean, horrek dakarren guztiarekin.» (Lehen Hezkuntzako ikaslearen gurasoa).

Sozialki mundua zabaltzeko hainbat estrategia baliagarri identifikatu dira. Horien artean dira Eskola Txikiek antolatzen dituzten txangoak, Institutu berera joango diren hainbat Eskola Txikietako ikasleak bilduta. Ekimen hori begi onez ikusten dute parte hartzaile guztiek. Badirudi teknolo- 
gia berriek eta komunikazio sare birtualek erraztu egiten dutela ikaskide izango direnen arteko harremana. Txango horiek abagune dira teknologiei lotutako sare sozialak (Tuenti, Whatsapp, etab. ) abian jartzeko eta Institutua hasi bitartean harremana mantentzeko.

«Eskola batekin ibili ginen kanpoan jolasten, eta beste batzuek eskatu ziguten numeroa, eta jada whatsappetik daukagu taldea eta hitz egiten dugu. (...) Daukagu eskola pila batekoa. (...) Eskolaz kanpo oraindik ez gara hasi, baina esan digute ea nahi dugun gelditu, ezagutzeko» (Lehen Hezkuntzako ikaslea).

Beste estrategia baliagarria, ikasle eta gurasoen ustez, LH garaian DBHko ikastetxea dagoen lekuan eskolaz kanpoko ekintzetan parte hartzea da, izan ere, ondoren ikaskide izango dituzten ikasleak aurrez ezagutzeko aukera ematen die.

"Aurretik sortzen dute harremana, [beste herri batekoekin] biltzen dira, azken urteetan antzematen zaiek kristoren martxa darabiltela. Internetek ere bideak ireki dizkik. (...) Aurretik ezagututa (...) hori oso inportantea... mutilek 5. mailan futbola eta neskak ere bai nahi izanez gero.» (Bigarren Hezkuntzako Irakaslea).

Azkenik, ikerketan parte hartu duten ikasle, familia eta irakasleen ustez beste estrategia baliagarri bat Eskola Txikietako ikasle ohien lekukotza jasotzea da. Hots, aurreko urteetan Eskola Txikietatik Bigarren Hezkuntzara pasa diren ikasleen Institutuari buruzko informazioa eskuratzea. Balio dezake Bigarren Hezkuntzan aurkituko dutenaren berri izateko (gelako dinamikak, irakasleen ezaugarriak, irakaskuntza estiloa, etxeko lanak, ebaluazio-sistema...), espektatibak moldatzeko eta etorkizun hurbilera egokitzeko.

«Erreferentziak oso inportanteak dira, aurretik joaten direnean, erreferentziak, eta ikusten badute aurretik joan direnak ondo moldatu direla, hori ere inportantea izango da beraientzat.» (Lehen Hezkuntzako ikaslearen gurasoa).

Komunikazio fluxu hori modu informalean nahiz formalean gerta daiteke, hau da, ikasleek egunerokotasunean izaten dituzten harremanen testuinguruan edo ikastetxeak informazio-trukerako antolatzen duen ekimen baten baitan, adibidez ikasle oihak gelara gonbidatu eta beren esperientziak partekatuz.

«Behin edo beste egin dugu ekarri eskolara eta komentatu besteei nolako sentipenak edo...» (Lehen Hezkuntzako irakaslea). 
Familiako kideen garrantzia ere agerian geratu da. Parte hartu duten guraso batzuek etxean partekatzen dituzte seme-alabekin trantsizioak sortzen dizkien kezkak, espektatibak, ilusioak. Anai-arreba zaharrenen testigantzak ere garrantzitsuak dira.

«(...) baina datorkienari buruz jakinaren gainean jarri behar dituzu, erakutsi pixka bat, ezta? Honetara eta honetara jaisten da hara, eta han ikasteko era, metodoa, ezberdina da...» (Lehen Hezkuntzako ikaslearen gurasoa).

«Nere anaia zaharrenak (...) esaten dit oso erraza dela, eta erraz egingo dudala dena.»(Lehen Hezkuntzako ikaslea).

\subsection{Familien estrategia hezkuntzarekiko}

Irakasleen diskurtsoek iradokitzen dute familien posizio sozio-ekonomiko eta kulturalak ere baduela eraginik seme-alaben ibilbide akademikoan eta, ondorioz, trantsizioan. Baina badirudi hori bezain garrantzitsua dela familiek seme-alaben ibilbide akademikoarekiko dituzten estrategiak (espektatibak, inbertsio politikak, ikuskerak, balioespenak...), batik bat kapital kulturalari dagokionez.

«Familien inplikazio eta maila kulturala ere bada, nik uste horrek ere eragin handia daukala, etxeko jarraipena eta eskolakoa daukate, eta hori nabaritzen da.» (Lehen Hezkuntzako irakaslea).

"[Eskola Txiki jakin bateko] norbait izan badugu noizbait problemaren batekin, gurasoak oso gainean eduki ditugu. (...) Ikasle kaskarragoak direnean, babes handia [izaten dute].» (Bigarren Hezkuntzako irakaslea).

«Adi egon beharra dago, zeren eskola porrota erraza iruditzen zait [nire alabaren] kasuan, zeren erritmo hau nola jarraitzen duzu? Erritmoa zentzugabea da, zentzugabea 12 urteko batentzat.» (Derrigorrezko Bigarren Hezkuntzako ikaslearen gurasoa).

Dena dela, Eskola Txikietako familia batzuek kezka azaltzen dute beraiek izan behar duten inplikazioarekiko. Batzuen ustez ez dago garbi nolakoa izan behar duen familiaren laguntzak etxean. Gehiegi eskatzen zaielakoan daude, uste baitute irakaslearen rola hartzera iristen direla. Izan ere, ohikoak omen dira Eskola Txikietan berdinen arteko ikaskuntzara bideratutako teknikak, beraien seme-alabek zerbait ulertu ez badute ikaskideren batengana bideratzea, irakaslearengana baino. Ondorioz, mesfidantza sortzen zaie irakasleari dagokion rolarekiko. Hori irakaskuntza metodologiaren inguruko ezagutza faltarekin lotuta dator. 


\subsection{Komunitate sendoetan sortutako sinergiak}

Familien estrategiei zuzenki lotzen zaion beste aldagai lagungarria, guraso eta irakasleen arabera, eskolak hurbileko komunitatearekin (familiarekin eta herriarekin batik bat) harreman estua eta egokia izatea da. Oinarrian lau eragile daudela esan daiteke: ikasleak, familia, eskolako langileak eta herria. Harreman estu horiek posible egiten dute Bigarren Hezkuntzarako bidean ikasleak hezkuntza dinamikarako testuinguru ustez egokiagoa batetik abiaraztea. Sinergia horiek gauzatu daitezen, badirudi eskola ardatza dela bi zentzutan. Batetik, irakasleen, gurasoen eta ikasleen arteko hurbileko harremana bultzatzen du.

"Guk kezka hori zaukaagu, [seme-alabak] nola ari diren, irakasleek ere badaukate kezka ume horiek gero etxean zer esaten duten. (...) Guk behar diagu beren informazioa, baina beraiek behar dute gure informazioa. Nik uste diat oso inportantea dela Eskola Txikietan binomio bat, eskola handitan ez dena ematen, harreman hori.» (Bigarren Hezkuntzako ikaslearen gurasoa).

«Gurasoekin daukagun harremana [oso garrantzitsua da]. Jakitea bere ama edozein momentutan hemen sartzen dela eta berarekin hitz egiten dugula, edo aita (...) Harreman estuago bat egiten saiatzen gara. (...) Hori umeek sentitzen dute, bizitzen dute.» (Lehen Hezkuntzako irakaslea).

«Edozein proiektu egiteko behar dugu beraien [familien] laguntza.» (Lehen Hezkuntzako irakaslea).

Bestetik, hurbileko erkidegoko beste kide batzuen inplikazioa eta kolaborazioa bilatzen du. Sinergia horiek eraginkorrak direnean ugariak dira ondorio positiboak, herriak biziagotu egiten dira, besteak beste, ikasleak bertan geratzen direlako, familiek elkar ezagutzen dutelako, herriari lotutako identitatea indartzen delako, eskoletatik abiatzen diren dinamikak herrira hedatzen direlako.

«Proiektuekin lana egiteak laguntzen digu inplikazioa handia izaten, denak inplikatzen ... herriarekin baita ere (...) gonbidatuta daude herriko aitona-amona guztiak (...) horrek ere laguntzen digu guk haiek ezagutzen, haiek gu ezagutzen (...) azken finean, eskola, herriko beste erakunde bat da.» (Lehen Hezkuntzako irakaslea).

«Herri txiki bat da eta denak direkzio berdinean goaz, eskola, udaletxea, gurasoak, elkartea.» (Bigarren Hezkuntzako ikaslearen gurasoa).

«[Gurea] duk herri bat oso dinamikoa, aktibitate pila bat, oso dinamikoa, hain biztanle gutxi izateko, eta horren alma mater, horren bihotza, eskola da. (...) Hemen aktibitate pila bat sortzen dituk, eta gero aktibitate horiek trasladatzen dituk herrira.» (Bigarren Hezkuntzako ikaslearen gurasoa). 
«Beste puntu inportante bat da eskolak herriarekin daukan lotura. Azken baten, umea proiektuetan sartuta baldin bazegok eskolan, ba, herri giroan sartuta zegok, eta kasi-kasi behartu egiten dizkik bere gurasoak, lotura handiak ez zeukatenak igual herriarekin, lotu egiten dizkik, etorri egiten dituk, harreman bat sortzen dute inguruarekin. (...) Eta hori oso inportantea duk. (...) Eta ez umeei bakarrik, gurasoei ere bai.» (Bigarren Hezkuntzako ikaslearen gurasoa).

«Herri txikia izanik, bueno, herrian bertan eskola edukitzea oso inportantea da, herriari asko ematen diolako, umeak hemen hezteak beste bizitasun bat ematen dio herriari. (...) Eskola handiago batera joango balira, hau hilda egongo litzateke astean zehar.» (Lehen Hezkuntzako ikaslearen gurasoa).

\subsection{Eskola Txikietan lortutako prestakuntza akademikoa}

Eskola Txikian erdiesten duten trebakuntzari buruzko bi ikuspegi azaleratu dira parte hartzaileen diskurtsoetan: batetik, ondo prestatuta ateratzen direla adierazten duena, eta, bestetik, alderdi horri buruz esplizituki ezer esaten ez duena, isiltasun bat, era askotara interpreta daitekeena.

«Nire ustetan ez daude prestatua salto hau egiteko.» (Bigarren Hezkuntzako irakaslea).

"Nik uste dut akademikoki, orokorrean, gehienak ondo prestatuta joaten direla. Lehenago esan duguna: hemen arazoak dauzkanak, ziur aski, han ere arazok izango ditu.» (Lehen Hezkuntzako ikaslearen gurasoa).

"Gehienek arazorik gabe egiten dute aurrera ikasketetan. Hala adierazten dute azken urteetako datuek.» (Bigarren Hezkuntzako irakaslea).

Lehen Hezkuntzan jasotako prestakuntza akademikoak trantsizioan eraginik baduen aztertzeko behaketak burutu dira ikasgeletan, eta bi etapetako ikasleen koadernoak aztertu. Institutuan hasierako hilabeteetan egiten dituzten ikaskuntza ariketak eskatzen dituzten eragiketa motak Eskola Txikietako proiektu bidez metodologietan nahiz berariazko arloetan ere agertzen direla ikusi da.

Ikusi da LHtik DBHko 1. mailara koska dagoela ikaskuntza-eduki kontzeptualetan: hiztegi berria, gramatika-egitura konplexuagoak eta adierazpen abstraktuagoak (aljebraren hastapenak, adibidez). Ezezaguna den eduki hori, irakasleen esplikazioak lagungarri direla, testu liburuen planteamendu didaktikotik irakasten da Institutuan, eta arakatze sistematizazio eta egituratze jardueren bidez jasotzen dute ikasleek. Jarduerak banan-bana isolatuta eta segida jakinetan burutzen dira, testu liburuetan datozen hurrenkera berean ia beti.

Eskola Txikietan proiektukako metodologia erabiltzen denean, problemak ebazteko jarduerak eta integraziokoak eskatzen zaizkie ikasleei. 
Problemak ebazteko jarduera elkarri lotutako ikaskuntza multzoa, era askotako jardueraz osatua, egoera eta zeregin baten aurrean aplikatzeari dagokio, erantzunak emateko. Ikasleek bibliografia arakatzen, landa lanean eta ekoizpenean dihardute. Ikaskuntza proiektu berriek, lehendik ezagutzen dituzten jarduera eta proiektu sinpleagoekin zerikusia eta antza duten neurrian, izaera integratzailea dute, zentzua ematen diote ikaskuntza prozesuari hainbat ezagutza egoera bateratuz. Eskola Txikietako heziketak ikasteko mugitzera behartzen ditu ikasleak, baita lana aurrera ateratzeko erantzukizuna lehen unetik beren gain hartzera. Ezinbestekoa da baliabideak bilatzea eta erabili eta zaintzea, norberarenak eta ingurukoak, . Jarrera hori oinarrizko osagaia da trantsizio garaian ere, zailtasun egoeretan aurrera egiteko.

Proiektuen bidezko ikaskuntzak planteamendu didaktiko globalizatuak eta inguruarekin lotura dutenak eskatzen ditu. Ikaskuntzaren ikuspegia holistikoa da, izaera konplexua osagai isolatu bakunak eta horien arteko loturak aintzat hartuz ulertzen duena. Izaera hori bi norabideko erlazio esanguratsuak sortuaz eraikitzen da, proiektuari aldian aldiko osotasunean begiratuta elementu sinpleak hautemanez batzuetan, elementu berriak proiektuari erantsiz hurrena. Ikaskuntzaren ikuspegi horrek ez ditu arakatze jarduera bakunak alde batera uzten; aitzitik, funtsezkoak dira horiek, ezinbesteko urratsak dira zeregin konplexuak ulertzeko.

Hori dela eta, ikaskuntza-sistema konplexu horretan hezitako ikasleek ez dute zailtasun nabarmenik aurkitzen Bigarren Hezkuntzan sartzen direnean, planteamendu didaktikoa askoz ere zatikatuagoa eta linealagoa baita hor, ezagutza arloko testu liburuak ezarritakoa gehienetan. Irakaskuntza eta ikaskuntza prozesuan, irakaslearen erabakien arabera antolatzen dira espazioen erabilera, denbora eta curriculuma ia beti. Irakasleek esandako materialak erabiltzen dituzte, batik bat, ikasleek. Trantsizioa gehiago da irakasteko eta ikasteko moduetara egokitu eta ohitzea.

\subsection{Lehen eta Bigarren Hezkuntzak partekatzen dituzten ezaugarriak}

Eskola txikietan egindako behaketa eta solasaldi gidatuetan jasotako datuak aztertzerakoan ikusi da Lehen eta Bigarren Hezkuntzako ikastetxeek zenbait ezaugarri partekatzen dituztela. Ezaugarri horiek positiboki nahiz negatiboki baloratu badaitezke ere, badirudi antzekotasun hori funtzionala dela bi ikastetxeen arteko trantsizioa errazteko.

Zenbat eta bi etapetako ikastetxeek tamaina eta testuinguru antzekoagoa izan, orduan eta ikasleentzako lagungarriago dela ikusi da.

«Ez doaz ezta eskola munstro batera, Eskola Txikia da, bi linea, 20-22, hortxe gabiltza... eta futbol taldea osa dezakete (...) Antzekoak elkartzen dira, herri txikietakoak herri txikietakoekin, ezaugarri berdin- 
tsuak dituzte origenean (...) Adibidez, [herri txiki batetik handi batera], hori bai dela kontrastea.» (Bigarren Hezkuntzako irakaslea)

Eskola Txikietan azterketak, notak eta testu-liburuak agertzen hasten dira estreinakoz Lehen Hezkuntza bukatzear denean. Presentzia handiegirik ez duten arren, badirudi trantsizioari begira erabiltzen dituztela, Institutuan aurkituko dutenaren aurrean trebatzeko. Gurasoen diskurtsoetan ikusten da bereziki elementu berri horiek sartu nahia; Lehen Hezkuntzako irakasleen diskurtsoetan, berriz, zalantza gehiago azaleratu dira.

«Bueno, ba, egia da salto bat badagoela, eta guk ere... nik ez dut nahi haien modeloa hartu, ez nagoelako batere ados, baina bai konturatzen naiz gauza batzuetan hartzen ditudala gutxi batzuk, adibidez, azterketena. (...) esaten diet ikasleei... hau da entsaio bat, froga bat ikasten joateko azterketak nola diren, nola ikasi behar den, zeren ez dakite...» (Lehen Hezkuntzako irakaslea).

Landa-lanean bildu ditugun datuek iradokitzen dute aztertutako Eskola Txikietako eta Institutuetako irakasleen rolek zenbait antzekotasun dituztela. Ez dirudi Eskola Txikietan irakaslearen rol nagusia ezagutza transmititzea denik, baina hori ere egiten dute, eta, eraginkortasunez egiten denean, ikasleek adierazi digute estimatzen dutela, hala Lehen nola Bigarren Hezkuntzan.

«Arbelean jartzen digu zer lan egin behar diren [Institutuan] (...) baina esplikatu egiten digu (...) Irakasleak, nire ustez, oso ondo esplikatzen du.» (Derrigorrezko Bigarren Hezkuntzako ikaslea).

Ikasgelako behaketetan ikusi da aztertutako Eskola Txikietako zenbait irakaslek gidari lana egiten dutela. Horrek ez du esan nahi kasu horretan ikasketa prozesuaren erdigunean jartzen direnik, baizik eta gelako dinamikak irakasleek abiarazten eta bideratzen dituztela, ikasleei autonomia handia emanez, baina betiere irakaslea da lan erritmoaren eta ekoizpenaren bermatzaile. Irakaslearen rol horrek intentsitate oso txikiko zenbait gatazka sortzen ditu, eta, gatazkek aurrera egiten ez duten arren, rolen eta botere harremanen ezaugarriak azaleratzeko balio dute: gidaritzarekin batera agintea duen irakaslea dela, ikasleak zenbait ariketa egitera behartzen dituela, edo arauen betearazlea ere badela irakaslea. Dena dela, ikusi da baita ere malgutasun ezaugarri batekin dela agintari, izan ere, irakasleak lanetan parte hartzea eskatzen duen arren, ezezkoa ere onartzen du batzuetan.

Bukatzeko, familien ustez aldagai lagungarria da irakasle aldaketa asko ez izatea, eta guztiek antzeko eskakizunak eta irakaskuntza metodologia erabiltzea. Bereziki nabarmentzen dute hori tutoreei dagokienean, elkarren artean alde handiak egon daitezkeelako. 


\subsection{Tutoretza jarduerak}

Ikasleen ustetan lagungarria da DBHko 1. mailako irakasle tutoreek ikasleekin ezartzen duten harreman estiloa Eskola Txikiko irakasleek dutenera hurbiltzea. DBHko 1. mailako tutoreek adierazten dute hasierako asteetan ikaslearen egokitzapena zaintzen saiatzen direla, eta bilera bat izaten dute hiruhilero, notak berrikusi, egoera aztertu eta zer hobetu behar duten jakiteko, bai ikasle eta familiarekin.

«Lana egiteko eran gure tutorea eta [Eskola Txikiko irakasle jakin bat] antzekoak ziren. Zer edo zer ez badugu ulertzen, zeratu, esplikatu eta horrela.» (Bigarren Hezkuntzako ikaslea).

«Gurasoekin hartu-emana ere asko lantzen da lehenengo mailan, zer ohitura dauden etxean, zer aldatu emaitzen arabera...banan-banan denekin.» (Bigarren Hezkuntzako irakaslea).

«Esaten diezu: zurekin hitz egin behar dut; eta ez dizute inoiz esaten: a, ez, jolas-garaia $d a . . . E z$, ez. Irrikatan daude hitz egiteko. Ematen du pertsona bezala garrantzia ematen diozula. Zer moduz sentitzen zara ikastetxean? Eta lagunekin zerbait gertatzen da? Tristeago ikusten zaitut.» (Bigarren Hezkuntzako irakaslea).

Bestetik, Institutuan egiten dituzten tutoretza jarduerak lagungarri dira trantsiziorako, ikasketa teknikak eta bestelako ikaskuntza prozedurak ikastea ahalbidetzen baitie (agendaren erabilera, karpeta baten antolaketa egokia, lanak nola aurkeztu), eta laguntzen die berria den ikaskuntza metodologiara egokitzen.

\section{EZTABAIDA}

Lan honetan Eskola Txikitatik Derrigorrezko Bigarren Hezkuntzarako trantsizioa aztertu da, eta bereziki, trantsizioa errazten duten aldagaietan sakondu da; horiek izaera desberdinetakoak badira ere, datuek trantsizio esperientzia bizitzen ari direnentzat harreman sozialei lotutako ekimenek trantsizioa errazteko aldagai gisa garrantzia dutela adierazten dute. Nazioarteko ikerketetan ikusi da ikasleen trantsizioan kezka nagusiak lagun berriak egitea eta hierarkia sozial berrian egokitzea direla (Mackenzie, McMaugh eta O'Sullivan, 2012; Jindal-Snape eta Miller, 2008; Argos, Ezquerra eta Castro, 2011) eta ikerketa honetan ere ondorioztatu da lagun berriak egiteak duen erakargarritasuna, trantsizioa egiteko motibazio motor nagusia izatera iristen delarik.

Eskola eremutik, beraz, beharrezkoa da alderdi sozialaren inguruko ekimenen antolaketa bideratzea. Lan horretako protagonistek balorazio positiboa egiten dute Lehen Hezkuntzako ikastetxeen arteko txangoen antolaketaz, DBHn hasi aurretik ikasleek elkar ezagutzea ahalbidetzen duelako 
eta Institutua ezagutzeko egiten diren ate irekiko jardueretan ikasleen arteko interakzio aberasgarriagoa bidera dezakeelako. Sare sozial teknologiko berriek sortzen duten aukera ere identifikatu da ikerketan, eta, beraz, irakasleek teknologia horiek ezagutu eta ikasleei modu egokian esploratzeko aukera eman diezaiekete, harreman sare sozial horietatik kanpo geratzeak ondorio negatiboak izan ditzake-eta ikasleengan. Topaketa horiez gain adi segi behar diote LHko eskolek beraien ikasle ohien arrastoari. Horien testigantzak balia ditzakete DBHra doazen ikasleen eskura jartzeko, ikasgelan edo ikastetxe mailan horretarako saioak antolatuz. Eremu formalago batean egin daitezkeen ekimen horiek, bide batez, esparru informalagoetan elkartrukatzen den informazio fluxua areagotu eta biziagotu dezakete, agian.

Ikerketa honetan nabarmena da eskolaz kanpoko jarduerek harreman sare ez-formal horietan txertatzen laguntzen diela ikasleei eta, baita ere, aztertutako Eskola Txikiek komunitateko eragileen kolaborazioa eskatzen duen testuinguru aldekoa dutela. Zentzu horretan, ikastetxeak bere testuinguru hurbileko (Lehen eta Bigarren hezkuntzako eskolak dauden herrietako) hezkuntza eskaintza sarea ezagutzea eta eragileekin hezkuntza eskaintza horiek koordinatzea lagungarria izan daiteke ikasleak komunitatean dauden baliabideen baliagarritasuna aprobetxatzeko (eskolaz kanpoko jarduerak, herriko dinamikak, etab), trantsizioa errazte aldera. Are gehiago, Bejaranok (2005) dioen bezala LHko eta DBHko ikastetxeek elkarrekin eskolaz kanpoko jarduerak eta zerbitzuak eskaintzen dituzten auzoko beste erakunde sozialekin lan koordinatu, parte hartzaile eta bateratua egiteak trantsizioan ikasleek aurrez ezagutzen zituzten eragileekin jarraituko lukete lanean, eta hori ikasle eta familientzat lasaigarria izan daiteke.

Alderdi sozialari heltzeko gai garrantzitsuenetakoa ikastetxean elkarbizitza hobetzeko estrategiak antolatzea da. Ikasleek badakite arauen aldaketa datorrela etapa berrian, irakasleei konpromiso handiagoa eskatuko diena, eta kontziente dira onartu egin beharko dituztela jokabide-arauak eta irakasleen eskaerak (Argos, Ezquerra eta Castro, 2011; San Fabiá, 1999). Etapen arteko aldea gutxitzeko elementu bat izan daiteke Elkarbizitza planaren elementuak adostu eta partekatzea trantsizioan inplikatutako bi eskolen artean: arazoen aurreko arautegia, bullyingaren inguruko protokoloak, gaitasunen osagai sozial eta emozionalak, talde-estrategiak, talde arauen osaera landu daitezkeen tutoretza planeko elementuak, ikasle bakartuei berariaz zuzenduriko esku-hartze (Bejarano, 2005; Antúnez, 2005), elkarbizitza komisioaren rola indartzea (San Fabián, 1999), edota harrera-plana (Otaño, 1999). Koordinazio guneek lehenetsi beharko lituzketen gaiak dira elkarbizitzari lotutakoak, curriculumaren inguruko koordinazioaren aurretik (Antúnez, 2005). Horretaz gain, ikusi da tutoreen esku-hartzearen eta tutoretza saioen bidez alderdi sozialari lantzeaz gain ikaskuntza antolatzen ikasteko estrategiak garatzeko aukera zabaltzen dela. 
Bestetik, lanean ikusi da familien posizio-ekonomiko eta kulturalak eta beraien seme-alaben ibilbide akademikoarekiko dituzten estrategia positiboak (espektatibak, inbertsio politikak, ikuskerak, balioespenak...) aktibatzeak erraztu egiten duela ikasleen hezkuntza-ibilbidea, eta, halaber, trantsizioa. Era berean, famili giroan trantsizioaren inguruko komunikazio irekia izateak ere laguntzen die ikasleei trantsizioaren inguruko espektatibak doitzen. LHko eta DBHko ikastetxeen artean alde nabaria identifikatu da familia eta eskolaren arteko harremanean, urteak aurrera joan ahala harreman hori ahulagoa baita. Ordea, komunitatearen arteko harreman-sareekin bezala, familia eta eskolaren artean komunikazio eraginkorrak ikasleen trantsiziorako testuinguru egokia sortzen duela azpimarratu behar da. Horren harira, eskolek hainbat estrategia abiatu ditzakete: tutoreek familiak animatzea, senideen artean trantsizioaren inguruan hitz egitea, espektatibak, kezkak, ilusioak partekatzea, , anai-arreba zaharrago eta gazteenen arteko komunikazioa bereziki zaintzea. Bestetik, Margetts and Kienig-ek (2013) dioten bezala, familien trantsizioa ere zaintzeko estrategiak aktiba daitezke. Ikusi da Eskola Txikietako familiek irakaskuntza metodologiari buruzko kezka dutela. Horregatik, lagungarria izan daiteke horiei maiz metodologiari buruzko trebakuntza saioak eskaintzea. Lagunduko luke, batetik, familiek izan ditzaketen zalantzak uxatzen (berdinen arteko ikaskuntza, ebaluazio irizpideak, proiektuen metodologia zertan datzan...). Bestetik, balio lezake trantsizioaren ikuspegitik ikus dezaten Eskola Txikietako metodologia ez dela traba Bigarren Hezkuntzarako trantsizioan, kontrakoa baizik, trantsizio eraginkorra hauspotzeko beste metodologia batzuek baino eraginkorragoa dela. Horrez gain, trebakuntza-saioek balio dezakete bakoitzak zein zeregin dituen argitzen, ikasleen hezkuntza prozesu arrakastatsua bermatze aldera.

$\mathrm{Bi}$ etapen arteko eten pedagogikoek sor ditzaketen ondorio negatiboei aurre egiteko, beharrezkoa da hurbiltze eta kolaborazio pausuak ematea. Ikerketan ikusi da bi etapen arteko koordinazioaren elementu nagusiak ikasleen informazioa trukatzea, curriculumeko edukiak eztabaidatzea eta Institutua ezagutzeko bisitak antolatzea direla. Interesgarria litzateke koordinazioa ikasleen jarraipen indibidualizatura zuzentzetik harago, eskolek duten hezkuntza-ikuspegiaren inguruko eztabaida ardatz izatera pasatzea. Horrek eskatzen du eztabaidatzea, batetik, trantsizioaren dilemak, paradoxak, eta bestetik, trantsizioa hobetzeko proposamenak, ondo funtzionatzen duten horiek ikastetxe batetik bestera transferi daitezkeen ikusiz. Badirudi, ordea, ez dela erraza hezkuntza tradizio desberdinen artean bateratasun edo antzekotasun puntuak topatzea, elkarri eragin diezaioten (Gairin, 2005). Gainera, autore horrek trantsizioan egoera itxuraz kontraesankorra azaleratzen dela dio: batetik, ikastetxeen autonomia eta proiektu propioak garatzearen aldeko hezkuntza-legediak onartzen die eskolari autonomia pedagogikoa, eta, aldi berean, horrek seme-alabek ikasiko duten eskolak beraien artean koordinatuta egotekoa familia guztiek duten eskubidea urra dezake. 
Planteamendu instituzionala izan behar du kolaborazioak, ebaluazio eta hobekuntza etengabea eskatzen duena ikastetxe bakoitzaren barne antolakuntzan (Gairin, 2005; Mas, 2002). Monarcak (2013) ideia batzuk proposatzen ditu trantsizioa eskolako egiteko gisa ulertzeko. Gobernu organo guztiak inplikatzea (klaustroa, zuzendaritza, eskola kontseilua...), batzordeetan trantsizioa hobetzeko elementuei buruzko gogoeta egitea (irakasleen profila, metodologia eraginkorrak, autoebaluazioa, beste eskolekiko koordinazioa), eta irakasle indibidualen gogoeta bultzatzea, horretarako, tutoretza, alderdi metodologikoei eta erlaziozkoei arreta eskainiaz.

Bestetik, agerian gelditu da bi etapen artean badirela partekatzen dituzten hainbat ezaugarri, eta horiek erraztu egiten dutela ikasleen trantsizioa (azterketak, irakasleen rol batzuk etab.). Kontua da, ordea, ez dirudiela komenigarria guztiz baldintzatzea batak bestearen curriculum akademiko eta instituzionala. Izan ere, Bigarren Hezkuntza Eskola Txikietako metodologiaren ohiko bilakaera oztopatzera iritsi daiteke eta; ikerketa honetan ondorioztatu da Eskola Txikietan ohikoak diren ikaste egoera integratzaile multzoek ikasleen prestakuntza egokia bermatzen dutela. Trantsizioa ikuspegi dialektiko integratzaile batetik begiratzeak (Alfaro, 2004) eskatzen du, ikasleak ingurunera egiten duen egokitzapena aztertzeaz gain, galdetzea ea egokitzapen hori egokia den ikaslearen aberastasun eta garapenerako. Hau da, ikertzea, batetik, subjektuak testuinguru aldakorretara egokitzeko duen gaitasuna, baina baita kanpo testuinguru horren egokitasuna subjektuarekiko. Horrek eskatzen du bi etapetako ikastetxeek honakoaz gogoeta egitea: eskaintzen dituzten hezkuntza baldintzak egokiak ote diren ikasleek trantsizio positiboa egin eta alderdi pertsonal, sozial eta akademikoan egoki garatzeko.

\begin{abstract}
This paper studies the process of transition to Secondary school of students of Primary rural schools. Rural schools share certain specific characteristics which have an impact on student learning, as well as on the transition process. The objective of this study is to identify what might be the key variables that help or hinder the transition. To this end a research has conducted based on two case studies in two rural schools located in Gipuzkoa. Data was collected through 68 hours of classroom observation, the activity analysis of primary grade 6 and secondary grade 1 students'notebooks, 16 focus groups with students from 6 grade of Primary education and 1 st grade of Secondary educa-
\end{abstract}


tion, and his family and teachers belonging to these two Primary rural schools and two secondary schools. The results indicate that there are some key factors that facilitate this transition process such as pedagogical coordination, social relationships with peers, family strategies, synergies with the surroundings, the prior academic preparation, common elements shared between the primary and secondary schools and tutoring activities.

Keywords: educational transition, rural schools, family-schoolcommunity relationship

Este trabajo estudia el proceso de transición a la Educación Secundaria que realiza el alumnado de la escuela rural. Las escuelas rurales comparten algunas características específicas las cuales tienen consecuencias en el aprendizaje del alumnado, y también en el proceso de transición. El objetivo del trabajo es identificar cuáles pueden ser las variables claves que ayudan o dificultan la transición. Para ello se ha realizado una investigación basada en el estudio de caso en dos escuelas rurales ubicados en Gipuzkoa. Se han realizado 68 horas de observación, analizado los cuadernos del alumnado de $6^{\circ}$ de Primaria y $1^{\circ}$ de ESO, y llevado a cabo 16 grupos de discusión con alumnado de $6^{\circ}$ de curso de Primaria y $1^{\circ}$ curso de Educación Secundaria, y sus familias y profesorado perteneciente a estas dos escuelas rurales y sus dos centros de referencia de Secundaria. Los resultados indican que existen algunos factores clave que facilitan este proceso transitorio como son la coordinación pedagógica, la relación social con los compañeros, las estrategias familiares, las sinergias con el entorno próximo, la preparación académica previa, los elementos comunes que comparten entre ambas etapas y las actividades tutoriales.

Palabras clave: transición educativa, escuelas rurales, relación familia-escuela-comunidad

Cet article étudie le processus de transition aux élèves de l'école rurale a l'école secondaire. Les écoles rurales partagent certaines caractéristiques spécifiques, qui ont un impact sur l'apprentissage des élèves et dans le processus de transition. L'objectif de cette étude est d'identifier ce qui pourrait être les variables importants qui facilitent ou entravent la transition. À cette fin, on a mené une recherche basée dans l'étudie de cas dans deux écoles rurales situées à Gipuzkoa. On a fait 68 heures d'observation, analysé les cahiers des élèves du sixième cours deécole élémentaire et du premier cours d'école secondaire, et organisé 16 groupes de discussion avec des étudiants et ses familles et des enseignants appartenant à ces deux écoles rurales et ses deux centres secondaires de référence. Les résultats indiquent qu'il ya des facteurs cléf qui facilitent ce processus de transition; , telles que la co- 
ordination de l'enseignement, les relations sociales avec les pairs, les stratégies familiales, les synergies avec l'environnement immédiat, la préparation scolaire précédente, les éléments communs partagés entre les deux étapes et les activités de tutelle.

Mots clé: transition éducationnelle, école rurale, relation familleécole-communauté

\section{ERREFERENTZIAK}

Alfaro, J. (2004). Diagnóstico en Educación y transiciones. REOP, 15(1), 67-88.

Anderson, L. W., Jacobs, J., Schramm, S. \& Splittgerber, F. (2000). School transitions: Beginning of the end or a new beginning? International journal of Educational Research, 33, 325-339.

Angrosino, M. V., \& Mays de Pérez, K. A. (2000). Rethinking Observation. From Method to Context. In N. K. Denzin \& Y. S. Lincoln (Eds.), Handbook of Qualitative Research (pp. 673-702). Thousand Oaks, California: SAGE.

Antúnez, S. (2005). El cuidado de los procesos de transicion de primaria a secundaria: a modo de balance. Revista Aula de Innovacion Educativa, 142, 7-11.

Argos, Ezquerra eta Castro, (2011). Escuchando la voz de la infancia en los procesos de cambio e investigación educativos. Aproximación al estudio de las transiciones entre las etapas de educación infantil y educación primaria. Revista Iberoamericana de Educación, 54(5), 1-18.

Barbour, R. (2007). Doing Focus Groups. Thousand Oaks, California: SAGE.

Bejarano, R. (2005). Paso de etapa de primaria a secundaria. Revista Aula de Innovacion Educativa, 142, 18-19.

Bengoetxea, I., Arribillaga, A., Madariaga, J. M. (2012). La interacción educativa en una escuela de ámbito rural con alumnado inmigrante. Aula abierta, 40(3), 61-70.

Berlanga, S. (2003). Educación ene l medio rural: análisis, perspectivas y propuestas. Huesca: Mira editores.

Boix, R. (2004). La escuela rural: funcionamiento y necesidades. Barcelona: Cisspraxis

Boix, R. (2011). ¿Qué queda de la escuela rural? Algunas reflexiones sobre la realidad pedagogica del aula multigrado. Profesorado. Revista de Curriculum y Formacion del Profesorado, 15(2), 13 - 23.

Bru, E., Stones, T., Munthe, E., \& Thue, E. (2010). Students' perceptions of teacher support across the transition from primary to secondary school. Scandinavian Journal of Educational Research, 54(6), 519-533.

Bustos, A. (2007). Enseñar en la escuela rural aprendiendo a hacerlo. Evolución de la identidad profesional en las aulas multigrado. Profesorado. Revista de curriculum y formación del profesorado, 11, 1-26.

Bustos, A. (2008). Docentes de escuela rural. Análisis de su formacion y sus actitudes a traves de un estudio cuantitativo en Andalucia. Revista de Investigacion Educativa, 26, 485-519. 
Chedzoy, S.M. \& Burden, R.L. (2005). Making the move: Assessing student attitudes to primary-secondary school transfer. Research in education, 74, 22-35.

Crosnoe, R. (2009). Family-school connections and the transitions of low-income youths ad English Language Learners from middle school to high school. Developmental Psychology, 45(4), 1061-1076.

Cruz, J., Jiménez de Aberasturi, E., Leon, M. \& Martínez, A (2010). Estrategias de mejora del Practicum II en las escuelas rurales en la formación inicial del profesorado. In: J. Garaizar, J. M. Goñi (Koord.) Nuevos escenarios para el aprendizaje en la Universidad: Propuestas de innovación educativa de la UPV/EHU (pp. 123-138). Bilao: UPV.

Domènech, M. (2000). La acogida en la educacion secundaria obligatoria. Revista de Aula de Innovacion Educativa, 90, 68-72.

Etxebeste, L. F. (1994). Una experiencia de educacion multicultural urbana-rural en el Pais Vasco desde el pensamiento del profesor. Doktoretza Tesia. UPVEHU.

Gairin, J. (2005). El reto de la transicion entre etapas educativas. Revista Aula de Innovacion Educativa, 142, 12-17.

Galton, M., Morrison I. \& Pell, T. (2000). Transfer and transition in English schools: reviewing the evidence. International Journal of Educational Research, 33,341-363.

Ganeson, K. \& Ehcrich, L. C. (2009). Transition into High School: A phenomenologival study. Educational Psychology and Theory, 41(1), 60-78.

Garmendia, J. F. (2003). La enseñanza rural en Gipuzkoa. La labor de la diputación y los ayuntamientos (1900-1950). Doktoretza Tesia. UPV-EHU.

Gimeno, J. (1996). La transición a la educacion secundaria. Madrid: Morata.

Hamm, J. V., Farmer, T. W., Dasdiman, K., Gravelle, M. \& Murray, A. R. (2011). Teachers' attunement to students peer group affiliations as a source of improved student experiences of the school social-affective context following the middle school transition. Journal of Applied Developmental Psychology, 32, 267-277.

Hanewald, R. (2013). Transition between Primary and Secondary School: Why it is important and How it can be supported. Australian Journal of Teacher Education, 38, 61-74.

Horward, S. \& Johnson, B. (2004). Transition from primary to secondary school: Possibilities and paradoxes. In Proceedings AARE 2004 Conference, Australian Association for Research in Education. www.aare.edu.au/04pap/ how04184.pdf-tik lortua.

Janesick, V. J. (2000). The Choreography of Qualitative Research Design: Minuets, Improvisations, and Crystallization. In N. K. Denzin \& Y. S. Lincoln (Eds.), Handbook of Qualitative Research (pp. 379-400). Thousand Oaks, California: SAGE.

Jindal-Snape, D. \& Miller, D. (2008). A challenge of living? Understanding the psychosocial processes of the child during primary-secondary transition through resilience and self-esteem theories. Educational psychology Review, 20,217-236.

Kingery, J. N., Erdley, C.A. \& Marshall, K.C. (2011). Peer acceptance and friendship as predictors of early adolescents' adjustment across the middle school transition. Merrill-Palmer Quarterly, 57, 3. 
Lledó, A. I. \& Martínez, C. (2005). La transicion de primaria a secundaria: un trabajo de colaboracion. Revista Aula de Innovacion Educativa, 142, 20-24.

Mackenzie, E., McMaugh, A. \& O’Sullivan, K. (2012). Perceptions of primary to secondary school transitions. Challenge or threat? Issues in Educational Research, 22(3), 298-314.

Manzisidor, I. (2013). Gipuzkoako Eskola Txikien eta beren testuinguruaren egungo egoera eta etorkizuneko erronkak. Dokumentu argitaratugabea.

Margetts, K. \& Kienig, A. (2013). International perspectives on transition to school: reconceptualising beliefs, policy and practice. London: Routledge.

Mas, A. (2002). La formación de grupos de trabajo a partir de la coordinacion entre la educacion primaria y la secundaria. Revista de Aula de Innovacion Educativa, $116,46-48$.

Monarca, H. (2013). Aportes de la investigacion sobre transiciones escolares a la orientación educativa en ESO. REOP, 24(2),116-125.

Monarca, H., Rappoport, S. eta Fernández, A. (2012). Factores condicionantes de las trayectorias escolares en la transicion entre enseñanza primaria y secundaria. REOP, 23(3),49-62.

Monarca, H., Rappoport, S. eta Sandoval, M. (2013). La configuración de los procesos de inclusión y exclusión educativa. Una lectura desde la transicion entre Educacion Primaria y Educacion Secundaria. Revista de Investigacion en Educacion, 11(3),192-206.

Olano, M. (2012). Elkarrizketa. Mikel Olano. Gipuzkoako Eskola Txikietako lehendakaria. Hik hasi, 169, 16 - 22.

Otano, L. (1999). Los retos de esta transición. Cuadernos de pedagogia,282, 52-57.

Padilla, M.T. (2002). Técnicas e instrumentos para el diagnóstico y la evaluación educativa. Madrid: CCS.

Pietarinen, J., Pyhältö, K. \& Soini, T. (2010). A horizontal approach to school transitions: a lesson learned from Finnish 15-year-olds. Cambridge Journal of Education, 40(3), 229-245.

Pratt, S. \& George, R. (2005). Transferring friendships: Girls' and boys' friendships in the transition from primary to secondary school. Children \& society, 19(1), 16-26.

Rodríguez, G.; Gil, J.; García, E. (1996). Metodología de la investigación cualitativa. Málaga: Aljibe.

Ruiz Olabuénaga, J. I. (2009). Metodología de la investigación cualitativa. 4 Edición. Bilbao: Universidad de Deusto.

San Fabián, J. L. (1999). La escolaridad obligatoria. Transiciones y tradiciones. Cuadernos de pedagogia, 282,25-30.

Sepúlveda, M. P. \& Gallardo, M. (2011). La escuela rural en la sociedad globalizada: nuevos caminos para una realidad silenciada. Profesorado. Revista de Curriculum y Formacion del Profesorado, 15(2), 1 - 13.

Smith, J., Feldwisch, R. \& Abell, A. (2006). Similarities and Differences in Students' and Parents' Perceptions of the Transition from Middle School to High School, Research in Middle Level Education Online, 29,10, 1-9.

Smith, J.S., Akos, P., Lim, S. \& Wiley, S. (2008). Student and Stakeholder Perceptions of the Transition to High School. The High School Journal, 91, 3 , February-March. 
Stake, R. E. (2000). Case Studies. In N. K. Denzin \& Y. S. Lincoln (Eds.), Handbook of Qualitative Research (pp. 435-454). Thousand Oaks, California: SAGE.

Tonucci, F. (1996). Un modelo para el cambio. Cuadernos de Pedagogía, 247, 48-51.

Waters, S., Cross, D. \& Shaw, T. (2010). Does the nature of schools matter? An exploration of selected school ecology factors on adolescent perceptions of school connectedness. British Journal of Educational Psychology, 80, 381-402.

Waters, S. K., Lester, L. \& Cross, D. (2014). Transition to secondary school: Expectation versus experience. Australian Journal of Education, 58(2), 153-166.

Waters, S. K., Lester, L., Wenden, L. eta Cross, D. (2012). A theoretically grounded exploration of the social and emotional outcomes of transition to secondary school. Australian Journal of Guidance and Counselling, 22(2), 190-205.

Weller, S. (2007). «Sticking with your mates?»: Children's Friendship Trajectories during the transition from Primary to Secondary School. Children \& Society, 21, 339-351.

West, P., Sweeting, H. \&Young, R. (2010). Transition matters: pupils' experiences of the primary-secondary school transition in the West of Scotland and consequences for well-being and attainment. Research papers in Education, 25(1),21-50. 